Original article

\title{
A Discussion of Inbreeding Coefficients in the Herds of Turkish Grey Cattle by using Calpain and Calpastatin Gene Markers
}

\section{Süleyman Kök \\ Department of Genetics and Bioengineering, Faculty of Engineering, Trakya University, Edirne, Turkey}

\begin{abstract}
The Turkish grey cattle (TGC) is the only local indigenous breed in Thrace and Western Anatolia. They can survive, feed, and breed without human intervention in nature. They spend the whole year, including winter, as free herds. TGC breed is under threat of extinction. Therefore they are protected by the Republic of Turkey Ministry of Agriculture and Forestry. Our investigation was supplied that purebred 51 TGC from the ex-situ protection program and 79 purebred TGC from smallholders into various villages. The research was conducted by Trakya University. Was studied that three different Single Nucleotide Polymorphisms (SNP) in the genes of calpain and calpastatin in purebred TGC. Variants of (CAPN1 316 and CAPN1 4751 SNPs) Calpain and (UoG-CAST SNP) Calpastatin genes were searched to monitor whether maintained the genetic diversity of the breed. Genetic analyses conducted on 130 cattle that have no consanguinity indicate that inbreeding coefficients calculated in each locus differed from each other. Average $F_{I S}, F_{I T}$, and $F_{S T}$ values were determined as -0.0689 , - 0.0405 , and 0.0266 respectively. The average gene flow was estimated to be 9.1590 . The genetic variability was found to be mainly between families in subgroups (97.345\%). The genetic diversity of the breed is maintained according to the results of the purebred TGC samples.
\end{abstract}

Keywords: Inbreeding Coefficients, $\mathrm{F}_{\mathrm{IS}}, \mathrm{F}_{\mathrm{IT}}, \mathrm{F}_{\mathrm{ST}}$, Genetic diversity, Grey cattle.

Received: 17 September $2021 \quad * \quad$ Accepted: 29 September $2021 \quad * \quad$ DOI: https://doi.org/10.29329/ijiaar.2021.415.10

\footnotetext{
* Corresponding author:

Süleyman Kök, Department of Genetics and Bioengineering, Faculty of Engineering, Trakya University, Edirne, Turkey. Email:koks@trakya.edu.tr
} 


\section{INTRODUCTION}

The grey cattle (TGC) is believed to be a subpopulation of Bos taurus primigenius (including aurochs) (Felius et al., 2011). It is believed that TGC is relative to some of the local grey cattle living in Europe. There are many similar local breeds in Europe such as Bulgarian grey cattle in Bulgaria, Istrian (Croatia), Dalmatian Grey (Croatia), Slovenian podolian (Croatia), Katerin (Greece), Sykia (Greece), Hungarian Grey (Hungary), Cinisara (Italy), MareManna (Italy), Podolicia (Italy), Romanian steppe (Romania), Ukrainian Grey (Ukraine), Istrian (Yugoslavia) and Turkish Grey (Turkey). These are a group of similar breeds according to the European Association Animal ScienceAnimal Genetic Resources Data Bank resources (Soysal and Kök, 2006; Kök et al, 2017). TGC is the only local indigenous breed in Thrace and Western Anatolia. They can survive, feed, and breed without human intervention in nature. They spend the whole year, including winter, as free herds. TGC breeds are preferred by the breeders in rural regions because of their tolerance to cold and heat, and resistance to ecto- and endoparasites. Besides, 12 different TGC herds in 5 provinces are under in-situ protection by the Republic of Turkey Ministry of Agriculture and Forestry (Kök, 2017). The production of standardized goods has been encouraged by globalization, which resulted in specific breeds becoming more prominent and dominating other breeds, thus, threatening the genetic diversity of some populations. Consequently, some native breeds which inherit some important genes for disease resistance, environmental tolerance, and genetic diversity are about to become extinct. Genetic markers are divided into three categories, which are Protein and DNA markers based on blood and tissue samples, and morphological markers based on biometric measurements of animals. The breeds are classified with the use of various biochemical marker systems, alloenzymes, mitochondrial DNA, and Y-chromosomespecific markers (Özşensoy and Kurar, 2012). Polymorphic genetic markers used in genomic research define DNA sequencing which has many variants within a population. There are various methods developed for identifying the major genes. A single point mutation can result in genetic differences caused by base differentiations in loci. SNPs have been widely used in studies on genetic diversity, population structures, quantitative trait loci (QTL), marker aided selection (MAS) to investigate familial relationships. The data from databases such as GenBank, PubMed, LocusLink, Genome Sequence, the European Bioinformatics Institute (EMBL-EBI), Ensembl Genome Browser, NCBI have been utilized to get information about SNPs.

The frequency of homozygous individuals within a cattle population may increase with inbreeding. The estimated deviation of Hardy-Weinberg (HW) ratios in an inbred population is defined as the fixation index $\left(F_{I S}\right)$. In other words, the $F_{\text {IS }}$ value indicates the homozygosity rate in a specific locus as a result of inbreeding (Wright, 1969; Dorak, 2020). If there are no other factors (selection, mating of homozygous animals, division into subpopulations, etc.) except for inbreeding, then FIs value should be equal to the Wright's (Wright, 1965) coefficient of inbreeding (Nei, 1987). Savaşçı and Atasoy 
(2016), who studied the native Turkish cattle breeds to test the potential deviations from HW equilibrium, calculated the $\mathrm{F}_{\mathrm{IS}}(-0.01028)$ and found that there was a disequilibrium among the population with an excess of heterozygous cattle. On the other hand, Altınalan (2005) and Özşensoy et al. (2010) who investigated the Turkish Grey Cattle (TGC) population with respect to $\mathrm{F}_{\text {IS }}$ and HW equilibrium reported $F_{I S}$ values as 0.11930 and 0.05524 , respectively and concluded that the TGC population is at equilibrium. The calculated $\mathrm{F}_{\mathrm{ST}}$ value was 0.055 in Savaşçı and Atasoy's (2016) research on Turkish native cattle where only $5.5 \%$ of the genetic variation was explained by among-population while the rest $94.5 \%$ was explained by within-population differences. He also reported a moderate genetic variation among native cattle breeds. Özşensoy et al. (2010) reported a low genetic variation in Turkish native cattle populations with an $\mathrm{F}_{\text {ST }}$ value of 0.022 while Altınalan (2005) found an $\mathrm{F}_{\text {ST }}$ value of 0.05482 and reported a moderate genetic variation. In addition, the results showed that the $\mathrm{F}_{\mathrm{ST}}$ value among Eastern Anatolian Red Cattle (0.01776), TGC and Native Black Cattle (0.01553) was quite low and that there was little genetic differentiation among native cattle breeds (Altınalan, 2005). MacHugh et al. (1998) who worked with seven different cattle breeds (Jersey, Hereford, Holstein, Simmental, Aberdeen Angus, Kerry, and Charola) in Europe calculated the $\mathrm{F}_{\text {ST }}$ values as moderate among some breeds (0.050) and high among others (0.181) while Kim et al. (2002) reported the $\mathrm{F}_{\mathrm{ST}}$ values as low (0.0104) and moderate (0.09816) among some breeds of North Eastern Asian cattle. Based on the $F_{\text {ST }}$ values, the genetic differentiation among Portuguese native cattle was considered low (0.0326) and high (0.1898) by Mateus et al. (2004). Hansen et al. (2002) suggested that the genetic variation was moderate between Holstein and Canadian (0.079) and it was high between Brown Swiss and Jersey (0.190). Sharma et al. (2009) identified a moderate degree of genetic variation among 4 different breeds in India with respect to the calculated average $\mathrm{F}_{\mathrm{ST}}$ value $(0.106 \pm 0.021) . \mathrm{F}_{\mathrm{IT}}$ value shows the deviation of the heterozygosity in a population from the HW equilibrium. The $\mathrm{F}_{\text {IT }}$ value calculated by Savaşçı and Atasoy (2016) was $4.55 \%$ and the homozygosity was $4.5 \%$ higher than the expected value. Gene flow $\left(N_{\mathrm{m}}\right)$ refers to the actual number of migrating individuals in every generation from one population to another. The gene flow between populations is estimated using $\mathrm{F}_{\mathrm{ST}}$ for one locus and multiple loci (Nei, 1987). Savaşç1 and Atasoy (2016) suggested that the highest level of genetic migration was between Eastern Anatolian Red and Native Black cattle populations $\left(\mathrm{N}_{\mathrm{m}}=3.92\right)$ and stated that these two populations had higher genetic propinquity between them compared to the other populations. Calpain (CAPN1 316 and CAPN1 4751) and Calpastatin (UoG CAST) variants are candidate genes for beef tenderness (Kök et al, 2019; Rincón and Medrano, 2006). The marker panels used in the current study were also utilized for selective breeding for higher beef tenderness and the identification of intrafamilial and interpopulation genetic variations (Kök, 2017; Kök et al, 2019). We identified the alleles in the related loci for the SNP analysis in TGC and they were genotyped based on SNP traits. The genotypic traits as revealed by the molecular genetic study were used for the comparison of the TGC group bred in villages (in-situ) without being exposed to the environmental interactions to the ones bred in the ex-situ 
conserved herd in Bandırma Livestock Research Institute (BLRI). Purebred TGC was discussed with respect to the inbreeding coefficient (F-statistics). F-statistics, which provides useful information to define the structure of a population, is used to explain genetic variation on the basis of total populations, subpopulations, and individuals. The concept of F-statistics developed by Wright (1965 and 1969) has three sub-parameters, which are $\mathrm{F}_{\mathrm{IT}}, \mathrm{F}_{\mathrm{IS}}$, and $\mathrm{F}_{\mathrm{ST}}$.

\section{MATERIALS and METHODS}

\section{Animal Materials}

All the research materials were collected in 2013. Tissue samples were obtained from 79 purebred TGC that were bred in the villages of Çanakkale and Edirne provinces and then slaughtered in Keşan Slaughter House in addition to the blood samples taken from 51 purebred TGC ex-situ conserved herds in BLRI. BLRI ex-situ conserved herd is made up of purebred TGC taken from 12 enterprises in villages of five cities. The analyses were carried out in Trakya University Biotechnology and Genetics Laboratory.

\section{Research Methods}

Genomic DNA of the tissue and blood samples were taken from 130 purebred TGC were isolated using Fujifilm QuickGene-mini-80 device and commercial kits. The spectrophotometric $\mathrm{A}^{260 / 280}$ method was used to determine the amount of isolated DNA. Polymerase Chain Reaction-Restriction Fragment Length Polymorphism (PCR-RFLP) and Amplification Refractory Mutation System Polymerase Chain Reaction (ARMS-PCR) methods were applied in order to identify the UoG CAST and CAPN1 marker genotypes, respectively. This study, was followed by Kök and his colleagues' (Kök et al, 2017; Kök, 2017) procedures.

The primary sequences presented in Table 1 and the PCR Master Mix Contents in Table 2 were used for the DNA amplification. The PCR-RFLP method in Table 3, and the ARMS-PCR method in Table 4 were carried out following the protocols (with Bioneer My Genie 96 Thermal Block Device). In the ARMS-PCR method 334 base pair (bp) and 446 bp DNA fragments were used to work on CAPN1 4751 (AF_248054.2:g.6545C>T) and CAPN1 316 (AF 252504:g.5709C >G), respectively. The length of the DNA fragments that were obtained after the $523 \mathrm{bp}$ product was incubated for 4 hours at $37^{\circ} \mathrm{C}$ with $3 U$ RsaI restrictive endonuclease enzyme was used to determine the genotypes for the UoG-CAST (AY_008267.1:g.282C >G) in the PCR-RFLP method. 
Table 1. Primary sequences used in PCR and the end products

\begin{tabular}{|c|c|c|c|c|}
\hline Marker & \multicolumn{3}{|c|}{ Primer sequences $\left(5^{\prime}-3^{\prime}\right)$} & bp \\
\hline \multirow{2}{*}{$\begin{array}{l}{ }^{*} U o G \\
\text { CAST }\end{array}$} & \multicolumn{3}{|c|}{${ }^{1}$ Fop:CTCGACTGCGTACCAATTCCGAAGTAAAGCCAAAGGAACA } & \multirow{2}{*}{523} \\
\hline & \multicolumn{3}{|c|}{${ }^{2}$ Rop: ATTTCTCTGATGGTGGCTGCTCACT } & \\
\hline \multirow{4}{*}{$\begin{array}{l}* * \text { CAPN1 } \\
316\end{array}$} & \multicolumn{3}{|c|}{${ }^{3}$ Fip: TTTCCTGCAGCTCCTCGGAGTGGAAGGG } & 269 \\
\hline & \multicolumn{3}{|c|}{${ }^{4}$ Rip: GCTCCCGCATGTAAGGGTCCAGGG } & 228 \\
\hline & \multicolumn{3}{|c|}{ 'Fop: GCTGTGCCCACCTACCAGCATC } & \\
\hline & \multicolumn{3}{|c|}{${ }^{2}$ Rop: CAGGTTGCAGATCTCCAGGCGG } & $4+0$ \\
\hline \multirow{4}{*}{$\begin{array}{l}* * \text { CAPN1 } \\
4751\end{array}$} & \multicolumn{3}{|c|}{${ }^{3}$ Fip: GCATCCTCCCCTTGACTGGGGGGAAACCC } & 158 \\
\hline & \multicolumn{3}{|c|}{${ }^{4}$ Rip: GTCACTTGACACAGCCCTGCGCCGCA } & 231 \\
\hline & \multicolumn{3}{|c|}{${ }^{1}$ Fop: CCTGGAGTCCTGCCGCAGCATGGTCAAC } & 334 \\
\hline & \multicolumn{3}{|c|}{ ²Rop: AAGCTGCAGGAGCTGCCCAAAGCCAGGC } & דנת \\
\hline \multirow{2}{*}{\multicolumn{5}{|c|}{$\begin{array}{l}\text { *RFLP method **ARMS method, 'Fop: Forward o } \\
\text { primer, bp: Base pair } \\
\text { Table 2. PCR Master Mix Contents }\end{array}$}} \\
\hline & & & & \\
\hline \multirow{3}{*}{\multicolumn{2}{|c|}{ Primers }} & UoG CAST & CAPN1 4751 and CAPN1 316 & \\
\hline & & 20 pmol from Forward primer & 10 pmol from each inner primer & \\
\hline & & 20 pmol from Reverse primer & 1 pmol from each outer primer & \\
\hline \multicolumn{2}{|l|}{ dNTPs } & $600 \mu \mathrm{M}$ & $200 \mu \mathrm{M}$ & \\
\hline \multicolumn{2}{|l|}{$\mathrm{MgCl}_{2}$} & $18,25 \mathrm{mM}$ & $3 m \mathrm{M}$ & \\
\hline \multicolumn{2}{|c|}{ Tris-HCL pH 8,4 } & $20 \mathrm{mM}$ & $20 \mathrm{mM}$ & \\
\hline \multicolumn{2}{|l|}{$\mathrm{KCl}$} & $50 \mathrm{mM}$ & $50 \mathrm{mM}$ & \\
\hline \multicolumn{2}{|c|}{ TaqDNA polymerase } & $0,5 \mathrm{U}$ & $0,5 \mathrm{U}$ & \\
\hline
\end{tabular}

Table 3. The UoG CAST marker PCR protocol

\begin{tabular}{|c|c|c|c|}
\hline & Temperature & Time & Cycle \\
\hline Denaturation & $94^{\circ} \mathrm{C}$ & $30 \mathrm{sec}$ & \\
\hline Connecting & $\begin{array}{l}\text { Touchdown PCR was performed by going down from } 69^{\circ} \mathrm{C} \text { to } \\
61^{\circ} \mathrm{C} \text { in } 8 \text { cycles. Then it was continued with } 27 \text { cycles at } 61 \\
{ }^{\circ} \mathrm{C} \text {. }\end{array}$ & $30 \mathrm{sec}$ & 35 \\
\hline Synthesis & $72{ }^{\circ} \mathrm{C}$ & $30 \mathrm{sec}$ & \\
\hline
\end{tabular}

Table 4. CAPN1 4751, and 316 Markers PCR protocol

\begin{tabular}{llll}
\hline & Temperature & Time & Cycle \\
\hline Denaturation & $94{ }^{\circ} \mathrm{C}$ & $30 \mathrm{sec}$ & \\
\hline Connecting & $\begin{array}{l}\text { Touchdown PCR was performed by going down } 2{ }^{\circ} \mathrm{C} \text { from } 64 \\
{ }^{\circ} \mathrm{C} \text { to } 60^{\circ} \mathrm{C} \text { in each cycle. }\end{array}$ & $30 \mathrm{sec}$ & 35 \\
\hline Synthesis & $72{ }^{\circ} \mathrm{C}$ & $30 \mathrm{sec}$ \\
\hline
\end{tabular}


The products were electrophoresed (by Thermo Scientific Device, 120V, $80 \mathrm{~mA}$ ) on a $3 \%$ gel for 45 minutes and genotyped (by DNR Bio-Imaging Systems MiniBIS Pro). The fragments were measured with the use of a 100 bp DNA ladder and ImageSource (Spectronics Corporation) software (as shown in Figures 1 and 2).

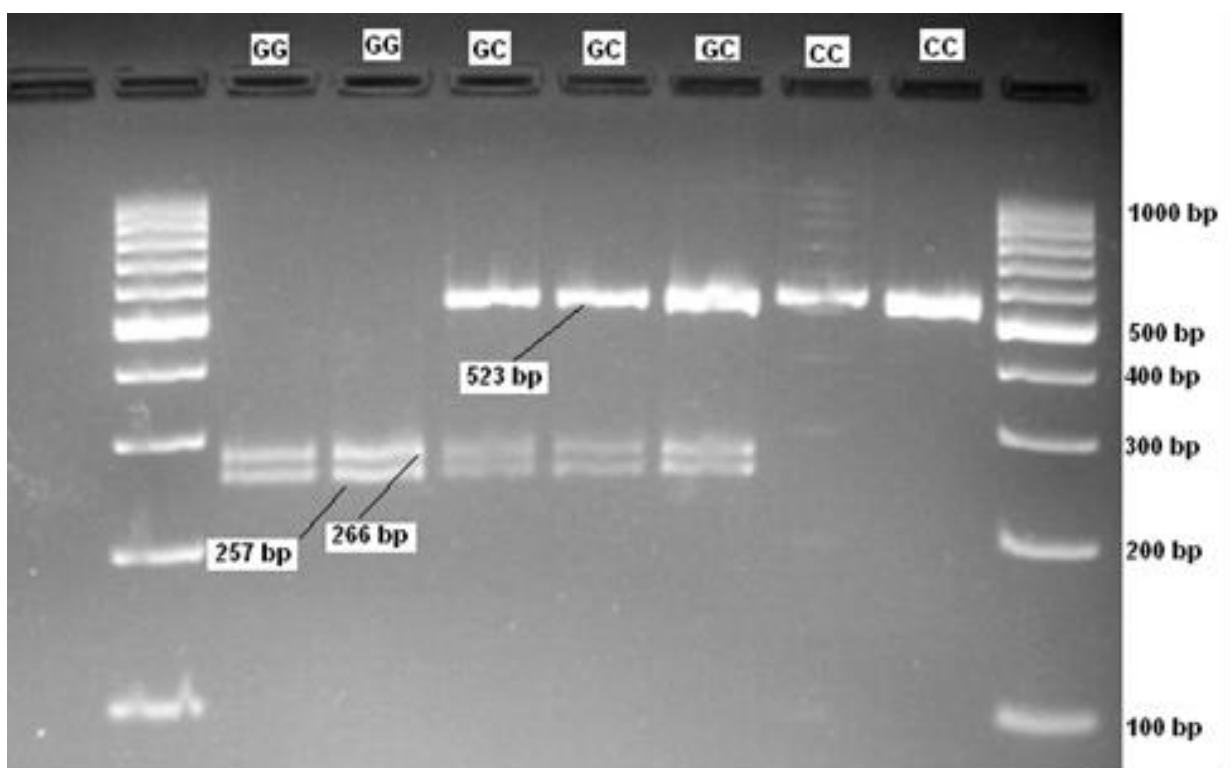

Figure 1. The three observed patterns on TGC UoG-CAST loci are defined as GG, GC, and CC genotypes with the RFLP technique.

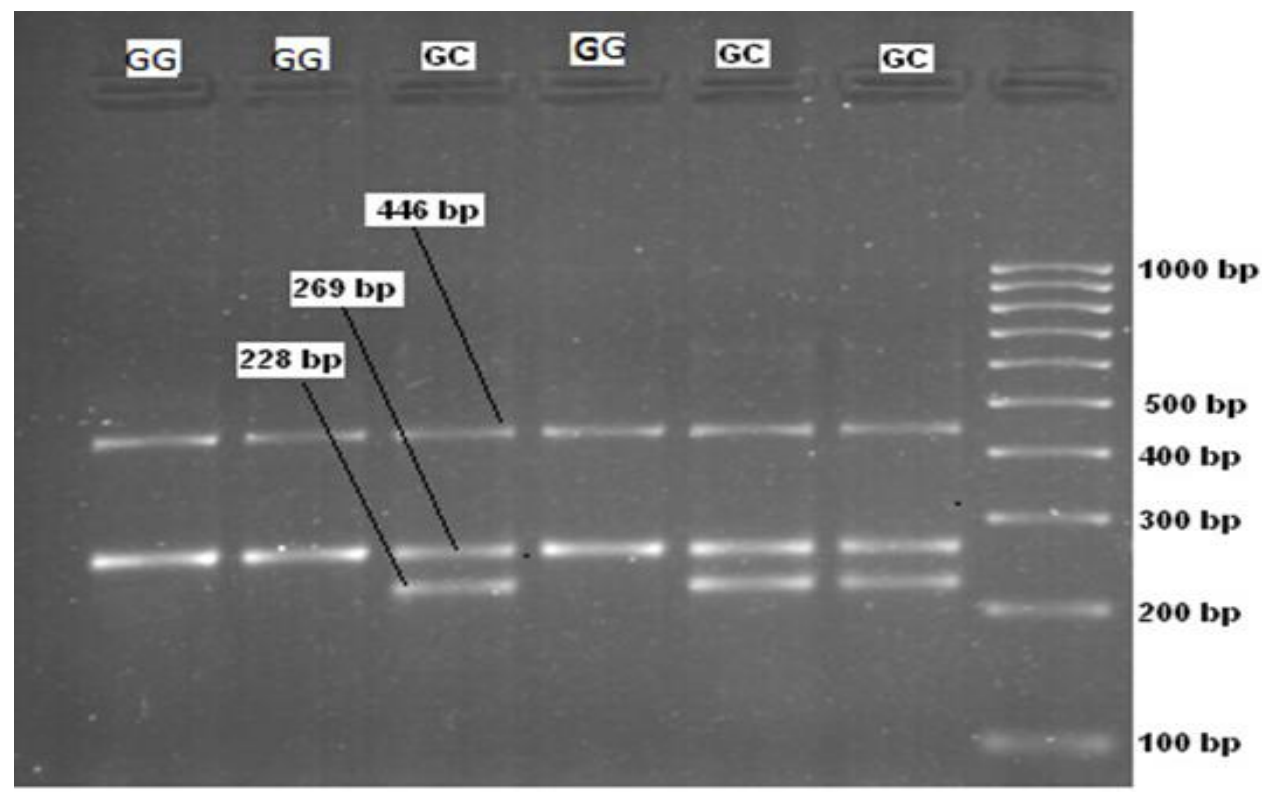

Figure 2. Agarose gel electrophoresis images of TGC CAPN1 316 loci SNP genotypes with ARMSPCR technique. In the gel, the cattle samples were defined as GC and GG. 


\section{Data Analysis}

The sample TGC was classified as; (a) the ones bred in the village environment, (b) the ones from ex-situ conserved herd in BLRI, (c) a total group including two subgroups. The Inbreeding Coefficients $\left(\mathrm{F}_{\mathrm{IT}}, \mathrm{F}_{\mathrm{ST}}, \mathrm{F}_{\mathrm{IS}}\right)$ were calculated with Popgene32 version 1.31 software (Yeh, 2000) based on Wright (Wright, 1965), Shannon index (I), and Estimated Gene Flow $\left(N_{m}\right)$ Nei (1987). FIT value shows the deviation of the heterozygosity in a population from the HW equilibrium. FST value (fixation index between subpopulations) is used to measure the genetic differentiation among subpopulations. If the $\mathrm{F}_{\text {ST }}$ value is between $0-0.05$, it indicates a low level of genetic differentiation. If it is between 0.05 and 0.15 , it indicates a medium level of genetic differentiation. An $\mathrm{F}_{\mathrm{ST}}$ value ranging from 0.15 to 0.25 means that there is a high level of genetic differentiation while an $\mathrm{F}_{\mathrm{ST}}$ value that is higher than 0.25 indicates a significant genetic differentiation (Wright, 1965). $\mathrm{F}_{\text {IS }}$ (individual within the subpopulation fixation index), which is also known as the inbreeding coefficient of the populations, indicates the average of increasing or decreasing heterozygosity.

\section{RESULTS and DISCUSSION}

The results of the study are evaluated in terms of two different subgroups based on their breeding style. Calpastatin and Calpain gene loci were found to be polymorphic in the samples TGC and genotypic differences were discussed with respect to the inbreeding coefficients. Whether the TGC population was in HW equilibrium was also investigated.

Two genetic variants (C and G/T) were detected in each of the UoG-CAST, CAPN1 316 and 4751 polymorphisms. The genetic characterization of the TGC in three loci was defined based on the pattern images of electrophoresis gel for the UoG-CAST SNP as follows; homozygous CC genotypes producing a 523-bp band and homozygous GG genotypes producing two bands (257 bp and $266 \mathrm{bp}$ ), heterozygous GC genotypes producing three bands (523 bp, $257 \mathrm{bp}$, and $266 \mathrm{bp}$ ) (Figure 1). With the use of the ARMS-PCR technique and based on the patterns on the electrophoresis gel, CAPN1 316 SNP genotypes were defined as follows; the ones that produced two bands with 228 and 447 bp were homozygous CC; the ones that produced three bands with 228, 269, and 446 bp were heterozygous CG; and the ones that produced two bands with 269 and 446 bp were homozygous GG (Figure 2). The ARMS-PCR method was also used for CAPN1 4751 SNP too. CAPN1 4751 SNP genotypes on the electrophoresis gel showed that samples produced two bands with 334 and $158 \mathrm{bp}$, three bands with 334, 231, and $158 \mathrm{bp}$, and two bands with 334 and 231 bp were homozygous CC, heterozygous CT, and homozygous TT, respectively.

\section{The Interpretation of the Inbreeding Coefficients}

The genetic interactions were tested for each and all the loci with $\mathrm{F}_{\mathrm{IS}}, \mathrm{F}_{\mathrm{ST}}$, and $\mathrm{F}_{\mathrm{IT}}$ indexes, and the results are presented in Table 5. All the three loci that we examined were polymorphic. The difference 
arising from the deficiency of heterozygous individuals on CAPN1 loci with a positive $\mathrm{F}_{\text {IS }}$ value was insignificant $(P>0.05)$. There was an excess of heterozygous individuals on the CAST locus with a negative $\mathrm{F}_{\mathrm{IS}}$ value, which was highly significant $(P<0.001)$. The negative $\mathrm{F}_{\mathrm{IS}}$ value of the CAST loci seems to influence the average $\mathrm{F}_{\text {IS }}$ value of the total TGC population, which results in excess of heterozygosity. The highest and lowest $\mathrm{F}_{\mathrm{IS}}$ value was estimated in the CAST and the CAPN1 316 (0.0037) locus, respectively. The number of heterozygous individuals in two TGC subgroups was $6.89 \%$ higher than expected.

Table 5. The tested F-statistics, in the TGC CAST, the CAPN1 4751, and 316 loci. And the determined gene flows for at the related to loci

\begin{tabular}{|l|l|l|l|l|}
\hline Loci & $\mathrm{F}_{\text {IS }}$ & $\mathrm{F}_{\text {ST }}$ & $\mathrm{F}_{\text {IT }}$ & ${ }^{\#} \mathrm{~N}_{\mathrm{m}}$ \\
\hline CAST & $-0,1977^{* *}$ & 0,0361 & $-0,1545$ & 6,6794 \\
\hline CAPN1 4751 & $0,0252^{\mathrm{ns}}$ & 0,0198 & 0,0444 & 12,4010 \\
\hline CAPN1 316 & $0,0037^{\text {ns }}$ & 0,0205 & 0,0241 & 11,9432 \\
\hline Mean & $-0,0689^{*}$ & 0,0266 & $-0,0405$ & 9,1590 \\
\hline
\end{tabular}

${ }^{\#} \mathrm{~N}_{\mathrm{m}}$; Gene flow calculated from the FST value. The importance level; * $(P<0.05), * *(P<0.001)$, ns Non- significant

The populations with a FIS value closer to zero are known to be at HW equilibrium (Özşensoy et al, 2010). Özşensoy et al., (2019) was determined the general $F_{I S}$ value to be 0.068 for all Turkish native cattle populations. Özkan (2005) reported that the $\mathrm{F}_{\text {IS }}$ value for Turkish native cattle ranged between 0.0368 and 0.1488 and that the populations were at HW equilibrium. But, Çobanoğlu (2018) and, Savaşçı and Atasoy (2016) calculated $\mathrm{F}_{\mathrm{IS}}$ mean were 0.2490 and -0.01028 , respectively, and Özbeyaz

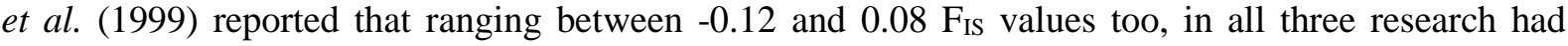
indicated that the populations were not at HW equilibrium with a significant difference $(P<0.05)$. On the other hand, Altınalan (2005) and Özşensoy et al. (2010 and 2019) stated that the TGC populations were at $\mathrm{HW}$ equilibrium with $\mathrm{F}_{\text {IS }}$ values of $0.11930,0.1230$, and 0.05524 , respectively. However, the calculated $\mathrm{F}_{\mathrm{IS}}$ value in our study $(-0.0689)$ was statistically significant $(P<0.05)$ and the TGC population was not in HW equilibrium according to our observations, except for the CAPN1 loci.

$\mathrm{F}_{\mathrm{ST}}$ is used to compare the average level of the heterozygosity deficiencies between populations with respect to a specific locus as a measure of genetic differentiation between subpopulations (Dorak, 2020). F FT was 0.0266 for three polymorphic loci in the current study showing an average decrease in heterozygosity at $2.66 \%$. As the calculated $\mathrm{F}_{\mathrm{ST}}$ ranged between 0 and 0.05 , the difference between the two subgroups was low (Wright, 1965; Dorak, 2020), which may be associated with the influence of homozygosity on the TGC population. In other words, the two-sample TGC groups (TGC in BLRI $e x$ situ conserved herd and TGC in village enterprises) had genetic similarities on specific loci. The genetic diversity in our TGC sample stemming from intragroup interfamilial differences was quite high (97.34\%). The decrease of heterozygosity in the inter-subgroups was highest on the CAST locus $\left(\mathrm{F}_{\mathrm{ST}}=\right.$ 
0.0361) while it was lower on CAPN1 4751 and CAPN1 316 loci. The fact that the genetic difference between sample groups was low supports that the TGC sample from the BLRI ex-situ conserved herd is almost identical with the TGC sample from the village enterprises, which proves the gene exchange between the two subgroups. The calculated average gene flow value $(\mathrm{Nm}=9.1590)$, confirmed that there was a considerable amount of gene flow between the two subgroups (Table 5). The TGC sample taken from the BLRI ex-situ conserved herd is very similar to the TGC sample taken from the village enterprises concerning genetic diversity.

There are several studies (Özbeyaz et al.1999; Altınalan, 2005; Özkan, 2005; Özşensoy et al., 2010; Savaşçı and Atasoy, 2016; Çobanoğlu, 2018) investigating the difference between populations of native Turkish cattle breeds. Özbeyaz et al. (1999) found a significant difference $(P<0.05)$ with an $\mathrm{F}_{\mathrm{ST}}$ value ranging between -0.12 and 0.08. Çobanoğlu's (2018), Altınalan's (2005), and Savaşçı and Atasoy (2016) an FST value studies whose were 0.065, 0.0548, and 0.0552, respectively, and in Özkan's study (2005) ranging between 0.0104 and 0.0344 demonstrated that the genetic differentiation was moderate. On the other hand, Özşensoy et al. (2010) reported an $\mathrm{F}_{\text {ST }}$ value of 0.022 and that the genetic differentiation among Turkish native cattle is quite low, which is in line with our findings (0.0266). The calculated $\mathrm{F}_{\mathrm{ST}}$ values of various studies on Turkish native cattle breeds seem to be close to ours, which points out low and medium levels of genetic differentiation.

$\mathrm{F}_{\mathrm{IT}}$ value is defined as the amount of deviation in the total group from the HW equilibrium as a result of considering all the individuals as a whole (Özkan, 2005). The $\mathrm{F}_{\text {IT }}$ value, one of the inbreeding coefficients, showed that the heterozygosity in the TGC population deviated from the HW equilibrium by $15.45 \%$ in the CAST locus and by $4.05 \%$ in the three loci (CAST, CAPN1 316 and 4751). In other words, the homozygosity for three loci in the TGC sample was $4.05 \%(-0.0405)$ below the expected, although it was not a significant difference $(P>0.05)$. According to Çobanoğlu (2018) and, Savaşçı and Atasoy (2016) the $F_{\text {IT }}$ value of $7 \%$ and 4.54 for Turkish native cattle, respectively, the actual heterozygosity level in the population for all individuals differs by compared to Hardy-Weinberg. Their $F_{\text {IT }}$ values were higher than our results.

Gene flow, which shows the gene exchange between populations within the same generation, were lowest on the CAST locus $\left(\mathrm{N}_{\mathrm{m}}=6.6794\right)$ while it nearly doubled in CAPN1 4751 (12.4010) and CAPN1 316 (11.9432) loci (Table 5), which forms a positive mechanism for genetic diversity. The genetic diversity was $56.86 \%(0.5686 \pm 0.1896)$ based on the mean Shannon Index (I) for the CAST and the CAPN1 loci in TGC, which showed that the population is at equilibrium. Çobanoğlu (2018) I value determined that $66 \%$ for Turkish native cattle and the population was at equilibrium too. The splitting into subgroups and shrinking of populations decreases the chance of random mating and increases the formation of monomorphic groups. To prevent homozygosity in groups, gene migration should be 
allowed and encouraged between TGC groups (the purebred TGC in BLRI and the TGC herds in the villages).

\section{Conclusion}

The inbreeding coefficients in Calpain (CAPN1 316 and CAPN1 4751) and Calpastatin (CAST) genes were defined and discussed referring to the related literature to contribute to the conservation and genotyping of purebred TGC genes. Understanding the genetic structure of the TGC population is an important contributor to the protection of the genotypic structure of the TGC breed, which is in danger of extinction. A decrease in genetic diversity was observed in TGC. The TGC in BLRI ex-situ conserved herd should be increased in number and interbred with new purebred TGC from different villages. Unless the genetic diversity is sustained, there will be increasing homozygosity that will result in decreasing resistance to environmental conditions, immunity to diseases, and feed conversion ratio in addition to the increasing deformations.

\section{Acknowledgement}

This study was supported by the Scientific Research Projects Commission of Trakya University with the project number TUBAP-2013-109

\section{REFERENCES}

Altınalan, A. (2005). Genetic characterization of microsatellite DNA markers in the indigenous cattle breeds in Turkey. Ph.D thesis, Çukurova University, Institute of Science and Technology, Department of Animal Science. pp 205, Adana, Turkey.

Çobanoğlu, Ö. (2018). Türkiye'de Yetiştirilen Bazı Sığır Irklarında GHR Geni Bakımından Genetik Çeşitlilik. Türk Tarım - Glda Bilim ve Teknoloji Dergisi, 6(10): 1329- 1333. Doi: 10.24925/turjaf.v6i10.1329-1333.1804

Dorak, M.T. (2020). Basic population genetics. http://www.dorak.info/genetics/popgen.html

Felius, M., Koolmees, P.A., Theunissen, B., European Cattle Genetic Diversity Consortium, \& Lenstra, J.A. (2011). On the breeds of cattle-historic and current classifications. Diversity. 3(4), 660-692, Doi: 10.3390/d3040660.

Hansen, C., Shrestha, J.N.B., Parker, R.J., Crow, G.H., Mc Alpıne, D,J., \& Derr, J,N. (2002). Genetic diversity among Canadienne, Brown Swiss, Holstein and Jersey cattle of Canada based on 15 bovine microsatellite markers. Genome. 45(5):897-904, Doi: 10.1139/g02-063

Kim, K.S., Yeo, J.S., \& Choi, C.B. (2002). Genetic diversity of North-East Asian cattle based on microsatellite data. Animal Genetics. 33(3): 201-204. Doi: 10.1046/j.1365-2052.2002.00848.x

Kök, S. (2017). Comparison of Genetic Diversity between the Ex-Situ Conservation Herd and Smallholders of Turkish Grey Cattle. Pakistan Journal of Zoology. 49(4): 1421-1427 Doi: 10.17582/journal.pjz/2017.49.4.1421.1427 
Kök, S., Atalay, S., Eken, H.S., \& Savasçı, M. (2017). The genetic characterization of Turkish grey cattle with regard to UoG Cast, CAPN1 316 and CAPN1 4751 markers. Pakistan Journal of Zoology. 49(1): 281-287. Doi: 10.17582/journal.pjz/2017.49.1.297.304

Kök, S., Atalay, S., Vapur, G., \& Soysal, M.İ. (2019). Siğırlarda Kalpain ve Kalpastatin Gen Polimorfizmlerinin Et Tekstürünün İyileştirilmesi Çalışmalarında Kullanımı. Lalahan Hayvancıllk Araştırma Enstitüsü Dergisi. 59 (2) 87-96

Mac Hugh, D.E., Loftus, R.T., Cunnıngham, P., \& Bradley, D.G. (1998). Genetic structure of seven European cattle breeds assessed using 20 microsatellite markers. Animal Genetics. 29 (5): 333-340. Doi: 10.1046/j.1365-2052.1998.295330.x.

Mateus, J.C., Penedo, M.C., Alves, V.C., Ramos, M., \& Rangel-Figueiredo, T. (2004). Genetic diversity and differentiation in Portuguese cattle breeds using microsatellites. Animal Genetics. 35(2):106-13. Doi: 10.1111/j.1365-2052.2004.01089.x.

Nei, M. (1987). Molecular Evolutionary Genetics, Columbia University Press, New York, p. 505, ISBN-13: 978-0-231-06321-0, USA.

Özbeyaz, C., Yıldız, M.A., \& Çamdeviren, H. (1999). Genetic relationships among cattle breed in Turkey. Journal of Lalahan Livestock Research Institute. 39(1): 17-32.

Özkan, E. (2005). An investigation on genetic structure of native and cultural cattle breeds in Turkey by using microsatellite markers. Ph.D thesis, Institute of Science and Technology, Department of Animal Science, Trakya University, pp. 235. Tekirdağ, Turkey.

Özşensoy Y, \& Kurar E (2012): Marker Systems and Applications in Genetic Characterization Studies. Journal of Cell and Molecular Biology. 10(2):11-19.

Özşensoy, Y., Kurar, E., Doğan, M., Bulut, Z., Altunok, V., Işık, A., Çamlıdağ, \& A., Nizamlıŏ̆lu, M. (2010). Türkiye'de Bulunan Bazı Yerli Sığır Irklarının STR Markörler ile Genetik Karakterizasyonu. Biyoloji Bilimleri Araştırma Dergisi. 3(1): 155-163.

Özşensoy, Y., Kurar, E., Doğan, M., Bulut, Z., Nizamlıŏ̆lu, M., Altunok, V., Işık, \& A., Çamlıdağ, A. (2019). Phylogenetic relationships of native Turkish cattle breeds using microsatellite markers. Turkish Journal of Veterinary and Animal Sciences. 43: 23-29, Doi:10.3906/vet-1805-10

Rincón, G., \& Medrano, J.F. (2006). Assays for genotyping single nucleotide polymorphisms in the bovine CAPN1 gene. Animal Genetics. 37(3): 294-295. Doi:10.1111/j.1365-2052.2006.01430.x

Savaş̧, M., \& Atasoy, F. (2016). The investigation of calpastatin and thyroglobulin gene polymorphisms in some native cattle breeds. Ankara Üniversitesi Veteriner Fakültesi Dergisi. 63: 53-59. Doi:10.1501/Vetfak_0000002709

Sharma, R., Pandey, A.K., Singh, Y., Prakash, B., Mishra, B.P., Kathiravan, P., Singh, P.K., \& Singh, G. (2009). Evaluation of genetic variation and phylogenetic relationship among North Indian cattle breeds. Asian-Australasian Journal of Animal Sciences. 22 (1): 13 - 19. Doi: 10.5713/ajas.2009.70047

Soysal, M.İ., \& Kök, S. (2006). The last survivor of grey cattle's whose resisting not to be extincted. A case study of characteristics and sustainability of traditional system of native grey cattle breed. $2^{\text {nd }}$ Seminar of the scientific-Professional Network on Mediterranean Livestock Farming. Mediterranean Livestock Production: Uncertainties and Opportunities, CIHEAM Publishing, pp. 55-63. Zaragoza, ES.

Wright, S. (1969). The theory of gene frequencies. III:Evolution and the genetics of populations, Volume 2, University of Chicago Press, Chicago, USA. 
Wright, S. (1965). The interpretation of population structure by F-statistics with special regard to systems of mating. Evolution, 19: 395-420. Doi: 10.2307/2406450

Yeh, F.C., Yang, R., Boyle, T.J., Ye, Z., \& Xiyan, J.M. (2000). POPGENE 32, Microsoft Window-based freeware for population genetic analysis, Version 1.32. Molecular Biology and Biotechnology Centre, University of Alberta, Edmonton, CA. 